\title{
HUBUNGAN PELAKSANAAN KOMUNIKASI TERAPEUTIK DENGAN TINGKAT KECEMASAN AKIBAT HOSPITALISASI PADA ANAK USIA SEKOLAH YANG DIRAWAT DI RSUD KAYUAGUNG TAHUN 2017
}

\author{
Mareta Akhriansyah ${ }^{1}$
}

\begin{abstract}
Anxiety is a confused worries and expanding, which is related beetween uncertainly and unpowerless. Anxiety will uppear as responce by stressor, for both phisical stressor and psycological stressor which can make un city till depression level of children. An also the effect of it is denial from the children to get any hospital treatment. Communication can reduce children anxiety hospitalized. The aim of this study was to know and influence of relationship beetween therapeutic communication implementation with anxiety level of school-age children while hospitalization.This study used correlation study, the sample is taking by quota sampling technique with 40 respondens. Anxiety level quesioner of children while hospitalized by Hamilton Rate Scale for Anxiety (HRS-A). Data analysis are using chi square $\left(x^{2}\right)$ formula. The result showed that therapeutic communication is influence to decrease a level of anxiety school-age children hospitalized ( $p=0,006$ $<\alpha=0.05)$. Nurse will be increasing therapeutic communication in every nursing treatment with children while hospitalized and also included their parents into their nursing treatments.
\end{abstract}

Key word : Anxiety hospitalized, therapeutic, communication

\section{PENDAHULUAN}

Hospitalisasi sering kali menjadi krisis pertama yang harus dihadapi anak. Anak- anak, terutama selama tahun-tahun awal, sangat rentan terhadap krisis penyakit dan hospitalisasi karena stress akibat perubahan dari keadaan sehat biasa dan rutinitas lingkungan. Reaksi anak terhadap krisis-krisis tersebut dipengaruhi oleh usia perkembangan mereka, pengalaman mereka sebelumnya dengan penyakit, perpisahan, atau hospitalisasi, keterampilan koping yang mereka miliki dan dapatkan, keparahan diagnosis dan sistem pendukung yang ada (Wong, 2009).

Anak yang dirawat di rumah sakit sering mengalami reaksi hospitalisasi dalam bentuk anak rewel, tidak mau didekati oleh petugas kesehatan, ketakutan, tampak cemas,

\footnotetext{
${ }^{1}$ STIK Bina Husada Palembang
}

tidak kooperatif, bahkan tamper tantrum. Menurut Ball dan Bindler (2003), anak yang dirawat di rumah sakit berada pada lingkungan asing yang tidak diketahuinya, dikelilingi orang-orang asing, peralatan, dan pemandangan sekitar menakutkan; sehingga menimbulkan reaksi hospitalisasi. Lebih kurang sejuta orang anak di bawah umur 17 tahun menjalani hospitalisasi di United States (Potts \& Mandleco, 2012). Di Indonesia sendiri setidaknya ada 35 per 1000 anak yang menjalani hospitalisasi (Sumatryoko, 2008 dalam Purwandari, 2009).

Hospitalisasi dapat menyebabkan anak ketakutan dengan paling sedikitnya satu alasan. Takut akan intervensi keperawatan, takut untuk menjadi pasien, dan takut sebagai tahapan dalam perkembangan mereka (Salmela, 2010). Hospitalisasi menyebabkan kecemasan dan secara emosional traumatis bagi anak. 
Lingkungan baru, orang asing dan peristiwa yang tidak menyenangkan seperti prosedur yang menyakitkan, menakutkan, dna menyedihkan untuk anak (Rohafza et al., 2009).

Kecemasan sangat berhubungan dengan perasaan tidak pasti dan ketidakberdayaan sabagai hasil penilaian terhadap suatu objek atau keadaan. Cemas timbul sebagai respon terhadap stres, baik stres fisik dan fisiologis. Artinya, ansietas terjadi ketika seorang merasa terancam baik fisik maupun psikologis. Ansietas adalah kekhawatiran yang tidak jelas dan menyebar, yang berkaitan dengan perasaan tidak pasti dan tidak berdaya dengan keadaan emosi yang tidak memiliki objek (Stuart, 2016).

Anak usia sekolah (6 sampai 12 tahun) mengandalkan pengalamanpengalaman masa lalu untuk menuntun mereka. Tergantung pada kualitas pengalaman masa lalu. Mereka mungkin tampak malu atau ragu-ragu selama pengkajian kesehatan. Seringkali mereka mungkin takut terluka atau merasa malu. Memberikan waktu untuk memperoleh ketenangan dari privasi (mungkin dari orang tua) membantu dalam komunikasi (Gunarso, 2005).

Perawat harus mengetahui teknik-teknik dalam berkomunikasi karena komunikasi merupakan cara yang dapat dilakukan untuk memberikan informasi tentang kesehatan. Komunikasi juga dapat mengurangi rasa cemas anak akibat hospitalisasi. Peran perawat dalam meminimalkan stres akibat hospitalisasi pada anak adalah sangat penting. Perawat perlu memahami konsep stres hospitalisasi dan prinsipprinsip asuhan keperawatan melalui pendekatan proses keperawatan (Hidayat, 2005).

Menurut Smith dan Watkins (2010), lingkungan terapetik meliputi efek psikososial lingkungan, efek lingkungan terhadap sistem immune, dan bagaimana pengaturan ruangan yang menarik. Setting ruang rawat anak yang menarik memberikan kesenangan tersendiri sehingga anak menjadi tidak cemas selama hospitalisasi. Anak yang kooperatif ketika dilakukan tindakan keperawatan merupakan salah satu tanda anak yang tidak cemas akibat hospitalisasi.

Teori lingkungan terapetik juga dapat digunakan untuk membantu anak dalam menghadapi stress hospitalisasi yang meliputi psikologi lingkungan (efek psikososial dari lingkungan), psychoneuroimmunology (efek lingkungan terhadap system immune); neuroscience (bagaimana pemikiran arsitektur atau desain ruang). Fasilitas pelayanan kesehatan untuk pasien diharapkan dapat meningkatkan kesehatan, keamanan, dan hubungan sosial yang normal, dan tidak terkesan mengisolasi. Desain lingkungan yang terapetik diperlukan untuk pasien di lingkungan rumah sakit (Smith \& Watkins, 2010). Ruang rawat anak perlu desain ruang menarik. Desain ruang yang terapetik di ruang rawat anak diantaranya penggunaan sprei bergambar, hiasan bergambar kartun, restrain infus bergambar, permainan terapetik, dan komunikasi perawat yang terapetik. Disamping itu kombinasi music dan seni dapat juga diterapkan. Terapi musik dapat dilakukan dengan diperdengarkannya musik yang disukai anak, sedangkan terapi seni dapat diterapkan dengan menggambar bebas.

Berdasarkan penelitian Redhian (2011), yang bertujuan untuk memahami dan menjelaskan bagaimana teknik atau cara yang digunakan perawat dalam melakukan komunikasi terapeutik dengan pasien anak dan juga orang tua. Hasil penelitiannya adalah pada saat pertemuan awal perawat dengan pasien anak untuk melakukan pengkajian awal 
pada pasien anak, jika pasien sudah bisa diajak berkomunikasi dengan baik, perawat tanyakan langsung pada anak tapi jika tidak langsung ke orangtuanya. Seringkali perawat melakukan komunikasi pada orangtua pasien anak. Teknik komunikasi yang digunakan perawat RSUD Ungaran gunakan hanyalah teknik bermain karena dianggap paling efektif. Cara komunikasi terapeutik yang perawat terapkan seperti posisi badan, jarak interaksi, nada bicara, melakukan sentuhan dan mengalihkan aktivitas cukup sering dilakukan perawat saat menghadapi pasien anak.

Ekawati (2010), dalam penelitian yang bertujuan menganalisis hubungan teknik komunikasi terapeutik dengan kecemasan pada anak sekolah di ruang perawatan anak Rumah Sakit Elisabeth Bekasi menunjukkan 11 responden yang menyatakan teknik komunikasi terapeutik perawat kurang baik. Terdapat 9 orang $(81,8 \%)$ mengalami kecemasan berat, 2 orang $(18,2 \%)$ mengalami kecemasan ringan sedangkan dari 19 responden yang menyatakan teknik komunikasi perawat baik. Terdapat 5 orang $(26,3 \%)$ mengalami kecemasan berat, 14 responden $(73,7 \quad \%)$ mengalami kecemasan ringan.

Menurut Cho \& Kim (2006), kecemasan anak usia sekolah membutuhkan kehadiran perawat sebanyak $87 \%$. Kecemasan akibat hospitalisasi dapat diminimalkan dengan kerja sama antara perawat dengan memberikan komunikasi terapeutik, orang tua, tenaga kesehatan yang lain dan anak itu sendiri.

Reaksi hospitalisasi pada anak usia sekolah sangatlah banyak dirasakan karena anak belum bisa menerima perpisahan dengan orang tua, anak usia sekolah merasa cemas karena tidak bisa bertemu dengan teman sebaya, lingkungan rumah sakit yang dirasakan terpencil, kesepian, asing dan ritinitas rumah sakit bisa sangat membosankan. Dari reaksi yang di timbulkan di atas akan memunculkan kecemasan dan ketakutan anak di rumah sakit (Supartini, 2004).

Perawat dan pasien diperbolehkan memasuki hubungan interpersonal yang akrab. Pasien berhak mengetahui tentang asuhan keperawatan yang diberikan oleh perawat sebagai petugas kesehatan yang profesional. Komunikasi perawat yang merupakan salah satu karakteristik komunikasi terapeutik.

Berdasarkan study awal yang dilakukan di ruang anak RSUD Kayuagung pada tanggal 02 Oktober 2017, didapatkan data bulan Januari sampai Desember 2016 sebanyak 1499 anak dirawat dan pada bulan januari sampai Agustus 2017 sebanyak 926 anak yang dirawat dengan kasus Thypoid, Demam Berdarah Dengue (DBD), KDS (Kejang Demam Sementara), Diare, ISPA (Infeksi Saluran Pernapasan Akut).

Berdasarkan hasil studi pendahuluan pada bulan Oktober 2017 terhadap 10 anak didapatkan 7 anak mengalami cemas dan 3 anak tidak cemas. Anak yang mengalami cemas terlihat diam dan bingung kemudian menangis dan memanggil-manggil ibunya pada saat perawat masuk kedalam ruangan perawatan anak. Ada juga anak yang mengamuk pada perawat mencoba berontak dan memaki perawat dan merajuk ingins egera pulang. Reaksi anak terhadap hospitalisasi sangat individual tergantung tahapan perkembangan, pengalaman, sistem dukungan yang ada dan kemampuan koping anak. Selama perawatan peranan orang tua sangat dominan dan penting.

Kurangnya penjelasan dan informasi pada waktu akan melakukan tindakan, kurangnya kunjungan atau pertemuan perawat dengan anak dan 
perawat jarang memperkenalkan diri kepada anak dapat menimbulkan cemas pada anak. Rasio jumlah tempat tidur adalah sebanyak 34 tempat tidur dan 3 - 4 perawat jaga, pastilah keberadaan perawat didekat pasien dirasakan sangat kurang. Sehingga komunikasi terapetik tidak bisa dilaksanakan dengan sebaik-baiknya.

Berdasarkan latar belakang di atas, maka penulis tertarik untuk melakukan penelitian dengan judul " hubungan pelaksanaan komunikasi terapeutik dengan tingkat kecemasan akibat hospitalisasi pada anak usia sekolah yang dirawat di RSUD kayuagung.

\section{METODE PENELITIAN}

Penelitian ini menggunakan rancangan studi korelasi (Correlation study) dengan menggunakan pendekatan Cross sectional yang bertujuan untuk mengetahui hubungan pelaksanaan kamunikasi terapeutik dengan tingkat kecemasan akibat hospitalisasi pada anak usia sekolah yang d irawat di RSUD Kayuagung. Populasi dalam penelitian ini adalah anak usia sekolah yang sedang dirawat di ruang anak RSUD Kayuagung dengan jumlah sampel sebanyak 40 responden. Penelitian ini dilakukan pada bulan Desember 2017.

\section{HASIL DAN PEMBAHASAN}

Hasil Penelitian yang dipaparkan meliputi tingkat kecemasan akibat hospitalisasi pada anak , Komunikasi Terapautik perawat, serta Hubungan pelaksanaan komunikasi terapeutik dengan tingkat kecemasan.

Tingkat Kecemasan Anak

\begin{tabular}{cccc}
\hline No & $\begin{array}{c}\text { Tingkat } \\
\text { Kecemasan }\end{array}$ & n & \% \\
\hline 1 & Cemas Ringan & 30 & 75 \\
2 & Cemas Sedang & 10 & 25 \\
& Total & 40 & 100 \\
\hline
\end{tabular}

Kecemasan anak terhadap hospitalisasi adalah cemas ringan yaitu $75 \%$..

Komunikasi Terapeutik Perawat

\begin{tabular}{llcc}
\hline No & $\begin{array}{c}\text { Komunikasi } \\
\text { Terapeutik }\end{array}$ & n & \% \\
\hline 1 & Cukup & 13 & 32,5 \\
2 & Baik & 27 & 67,5 \\
& $\quad$ Total & 40 & 100 \\
\hline
\end{tabular}

Komunikasi terapeutik perawat yang diterapkan adalah komunikasi baik yaitu $67,5 \%$.

\section{Hubungan Komunikasi Terapeutik dengan Tingkat Kecemasan}

Uji yang dilakukan menggunakan Fisher's Exact Test menunjukan nilai (signifikansi) sebesar 0.006. Karena nilai signifikansi $0.006<0,05$ sehingga didapat kesimpulan ada hubungan komunikasi terapeutik dengan tingkat kecemasan akibat hospitalisasi pada anak usia sekolah.

\section{PEMBAHASAN}

Ansietas adalah perasaan yang tidak menyenangkan, tidak enak, khawatir dan gelisah. Ansietas dapat menyebabkan ketidak seimbangan fisik, psikologis dan sosial (Wilkinson, 2016). Ketidak seimbangan fisik berupa keluhan-keluhan somatik (fisik), seperti perasaan panas atau dingin, mual, mulut kering (Stuart, 2016).

Hasil penelitian menunjukan bahwa responden dengan cemas sedang sebanyak 10 orang (25\%), dan responden dengan cemas ringan sebanyak 30 orang $(75 \%)$.

Anak usia sekolah adalah anak yang berusia 6-12 tahun. Karakteristik anak usia sekolah adalah suka berkelompok dengan teman sebaya sesuai jenis kelaminnya. Perkembangan kognitif anak memasuki tahap konkret yaitu anak sudah mulai memandang realistis dari dunianya dan mempunyai 
anggapan yang sama dengan orang lain.

Anak usia sekolah membayangkan dirawat dirumah sakit merupakan suatu hukuman, dipisahkan, merasa tidak aman dan kemandiriannya terlambat. Menjalani terapi pengobatan, diberikan terapi medis yang terkadang menyakiti anggota tubuh anak cenderung menjadikan anak cemas (Wong, 2009).

Komunikasi adalah suatu proses dimana informasi ditransmisikan melalui sebuah sistem simbol, tanda atau perilaku yang umum. Komunikasi dalam bidang keperawatan merupakan prose menciptakan hubungan antara perawat dan klien.

Hasil penelitian menunjukan bahwa distribusi komunikasi perawat cukup baik adalah sebanyak 13 orang $(32.5 \%)$ dan komunikasi perawat baik sebanyak 27 orang $(67.5 \%)$.

Uji statistic yang dilakukan menggunakan Fisher's Exact Test menunjukan hasil nilai (signifikansi) sebesar 0.006. Karena nilai signifikansi $0.006<0,05$, maka Ho ditolak, Ha diterima. Dari hasil uji tersebut dapat ditarik kesimpulan ada hubungan komunikasi terapeutik dengan tingkat kecemasan akibat hospitalisasi pada anak usia sekolah.

Reaksi hospitalisasi pada anak usia sekolah sangatlah banyak dirasakan karena anak belum bisa menerima perpisahan dengan orang tua, anak usia sekolah merasa cemas karena tidak bisa bertemu dengan teman sebaya, lingkungan rumah sakit yang dirasakan terpencil, kesepian, asing dan ritinitas rumah sakit bisa sangat membosankan. Dari reaksi yang di timbulkan di atas akan memunculkan kecemasan dan ketakutan anak di rumah sakit (Supartini, 2004).

\section{SIMPULAN}

Berdasarkan hasil penelitian dan uraian pembahasan pada bab sebelumnya dapat disimpulkan

1. Sebagian besar responden mengalami cemas ringan sebanyak 30 orang $(75 \%)$.

2. Sebagian besar komunikasi perawat adalah baik sebanyak $27(67,5 \%)$.

3. Ada hubungan komunikasi terapeutik dengan kecemasan akibat hospitalisasi pada anak usia pra sekolah $(\mathrm{p}=0.006<\alpha=0.05)$.

\section{Saran}

1. Bagi Rumah Sakit

Untuk lebih meningkatkan komunikasi dalam melakukan tindakan terutama perawat, dan melibatkan keluarga terdekat pasien dalam memberikan terapi yang diberikan.

2. Pendidikan Keperawatan

Hasil penelitian dapat dijadikan bahan pembelajaran di kampus tentang pentingnya melakukan komunikasi terapeutik untuk meminialkan dampak hospitalisasi pada anak

\section{DAFTAR PUSTAKA}

Ekawati,L. (2010) Hubungan teknik komunikasi terapeutik perawat dengan kecemasan Pada anak prasekolah di ruang perawatan anak rumah sakit elisabeth bekasi, Jurnal Penelitian, Bekasi.

Hawari, H. D. (2009). Manajemen Stress, Cemas, dan Depresi. Jakarta: Fakultas Kedokteran Universitas Indonesia.

Isaacs, Ann (2010), Keperawatan kesehatan jiwa dan psikiatrik. Jakarta : EGC

Potter, P. A \& Perry, A, G. (2013). Fundamental Of Nursing. 8th . Elsevier Mosby. St. Louis, Missouri

Saryono. (2008). Kumpulan instrument penelitian kesehatan. Yogyakarta: Mulia Medika 
Stuart, G. W. (2016). Prinsip dan Praktik Keperawatan Kesehatan Jiwa Stuart. Buku 1 \& 2. 1st Indonesia edition, by Keliat \& Pasaribu. Elsevier Singapore Pte Ltd.

Supartini, Y, (2004). Buku Ajar Konsep Dasar Keperawatan Anak. Jakarta: ECG.

Wong, L. Donna. 2009. Buku Ajar Keperawatan Pediatrik. Vol. 1. Edisi 6. . Jakarta : EG 